\title{
Üst gastrointestinal sistem stromal tümörlerinin endosonografik ve histopatolojik özelliklerinin karşılaştırılması: Tek merkez deneyimi
}

\author{
Comparison of endosonographic and histopathological features of upper GISTs: A single center experience
}

Nevin ORUÇ ${ }^{1}$, Ahmet AYDIN ${ }^{1}$, Fatih TEKIN ${ }^{1}$, Adem GÜLER², Sinan ERSIN², Müge TUNÇYÜREK ${ }^{3}$, Tankut ILTER ${ }^{1}$

Ege Üniversitesi Tıp Fakültesi Gastroenteroloji Bilim Dalı ${ }^{1}$, Genel Cerrahi Ana Bilim Dalı ${ }^{2}$, Patoloji Ana Bilim Dalı ${ }^{3}$, Izmir

\begin{abstract}
Amaç: Gastrointestinal stromal tümörler daha çok orta yaşlarda ortaya çıkan mezenkimal tümörlerdir. Endoskopik inceleme tanı için yetersizdir. Endosonografi gastrointestinal stromal tümörlerin incelenmesinde en sik kullanılan görüntüleme yöntemidir. Histopatolojik olarak mitotik aktivitesi yüksek olan büyük lezyonlar, malignite riski yüksek gastrointestinal stromal tümör olarak tanımlanmaktadır. Bu çalışmada gastrointestinal stromal tümörlerin endosonografi bulguları ile histopatolojik özellikleri arasındaki bağlantıların araştırılması amaçlanmıştır. Gereç ve Yöntem: Çalışmaya gastrointestinal stromal tümör şüphesi ile endosonografi yapılan ve opere edilerek histopato-

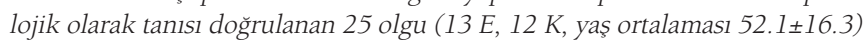
dahil edilmiştir. Bulgular: Olgularnn tümünde tümörler midede olup, 5’i kardia-fundus, 17'si korpus ve 3'ü antrum lokalizasyonludur. On (\%40) olguda, tümörün lüminal yüzeyinde ülserasyon varlığı izlenmiştir. Endosonografik olarak ölçülen tümör çapı ortalaması $51.59 \pm 20.37 \mathrm{~mm}$ olup histopatolojik

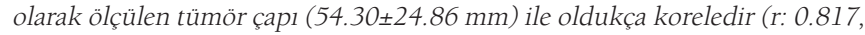
p<0,001). Histopatolojik incelemede NIH siniflamasina göre, 1 (\%4) olgu malignite yönünden çok düşük riskli, 8 (\%32) olgu düşük, 9 (\%36) olgu orta, 7 (\%28) olgu yüksek riskli olarak değerlendirilmiştir. Yüksek riskli gruptaki olguların tümünde tümör çapının 50 mm'nin üzerinde olduğu, ekstralüminal yüzeyde kenar düzensizliğinin bulunduğu ve tümörlerin anekoik ve hiperekoik alanlar içeren heterojen eko yapıda olduğu saptanmıştır. Sonuç: Bulgularımız, endosonografinin, gastrointestinal stromal tümörlerin tanısında ve malignite potansiyellerinin değerlendirilmesinde, güvenilir bir yöntem olduğunu göstermektedir.
\end{abstract}

Anahtar kelimeler: Stromal tümör, endosonografi, malignite, histopatoloji

\section{GİRIS}

Gastrointestinal stromal tümör'ler (GIST) gastrointestinal sistemin en sik izlenen mezenkimal tümörleridir (1). Daha çok orta yaşlarda ortaya çıkan bu tümörler, nadiren genç olgularda da bildirilmektedir (2). Histopatolojik olarak "tyrosin kinase receptor" (c-KIT) markırı olan CD 117 pozitif mezenkimal tümörler GIST olarak tanımlanmaktadır (3).

Endoskopik incelemeler sırasında tesadüfen saptanan subepitelyal lezyonların değerlendirilmesi ve sinıflandırılması zordur. Bu nedenle ek görüntüleme yöntemlerine başvurulur (4). GIST'lerin tanı ve takibinde endosonografi (EUS), bilgisayarlı tomografi, MRI ve fluorine-18-flouro-deoxyglucose (FDG) PET sıklıkla kullanılan görüntüleme yöntemleridir (5, 6). Bunlar arasinda EUS subepitelyal patolojilerin incelenme-
Background and Aims: Gastrointestinal stromal tumors are mesenchymal tumors mostly prevalent at middle ages. Since endoscopy is insufficient for evaluation of gastrointestinal stromal tumors, endoscopic ultrasound is preferred and mostly used imaging technique. Gastrointestinal stromal tumor lesions with high mitotic activity and large tumor size are usually considered to have a malign potential. We aimed to investigate the correlation between the endoscopic ultrasound findings and histopathologic characteristics of gastrointestinal stromal tumors. Materials and methods: Twenty five patients who underwent endoscopic ultrasound fort he suspicion of gastrointestinal stromal tumor and have the definitive diagnosis of gastrointestinal stromal tumor histopathologically were included to the study (13M, 12F, mean age 52.1 1 16.3). Results: All gastrointestinal stromal tumors were located in the stomach; five of them in the fundus, 17 in the corpus and 3 in the antrum. There were ulcerations on 10 (\%40) gastrointestinal stromal tumor lesions. Mean diameter of the gastrointestinal stromal tumors measured during endoscopic ultrasound evaluation $(51.59 \pm 20.37 \mathrm{~mm})$ was highly correlated with the real tumor size $(54.30 \pm 24.86$ mm, $r: 0.817, p<0,001)$. National Institute of Health classification of the gastrointestinal stromal tumors revealed 1 (\%4) with very low risk, 8 (\%32) with low risk, 9 (\%36) with intermediate risk and 7 (\%28) with high risk for malign potential. All gastrointestinal stromal tumors with high risk for malign potential had anecoic or hyperecoic areas, irregular extraluminal borders, and their size were larger than $50 \mathrm{~mm}$ on endoscopic ultrasound. Conclusions: Our findings indicate that endoscopic ultrasound is reliable method in diagnosis and predicting the malign potential of gastrointestinal stromal tumors.

Key words: Stromal tumour, endoscopic ultrasound, malignancy, histopathology

sinde ve tanısında tercih edilen yöntemdir. EUS leiomyom, leiomyosarkom gibi diğer mezenkimal tümörlerle GIST'lerin ayrımında yararlı bulunmuştur (7). EUS bulguları tümör aktivitesi ve malignite açısından yararlı ek bilgiler verebilmektedir (8). Ayrıca EUS eşliğinde ince iğne aspirasyon biyopsisi (EUS-FNA) yapılarak GIST tanısı histopatolojik olarak doğrulanabilmektedir (9).

GIST'lerin tümünde malignite riski bulunduğu kabul edilmektedir (10). Malignite riski çok düşükten yüksek dereceye kadar değişebildiği için, değerlendirilmesi gerekli, ancak zordur. Tümör çapı ve mitotik aktivite malign potansiyeli belirlemede en önemli parametrelerdir $(11,12)$. Histopatolojik incelemede 50 büyük büyütmede beş ve üstü mitoz malign 
davranış potansiyelini göstermektedir. Ancak mitotik aktivitesi düşük tümörler arasında da çok az oranda metastaz bulguları ortaya çıkabilmektedir. Bu nedenle düşük mitotik aktivite malign potansiyel olasılığını tamamen ortadan kaldırmaz (12). Diğer taraftan tümör çapının 2 cm'den küçük olması çok büyük olasılıkla benign tümör anlamına gelmektedir (13). GIST'lerin malign potansiyelini belirlemek için National Institutes of Health (NIH) histopatolojik verilere dayanarak bir sınıflama geliştirmiştir (14) (Tablo 1). Ancak bu sınıflama cerrahi rezeksiyonla lezyonun tamamının çıkarılmasını gerektirmekte, bu da her vakada mümkün olmamaktadır.

GIST olgularının tanı ve takibinde kullanılan EUS tümörün malign potansiyeli hakkında bilgiler verebilir. Buradan yola çıkarak, bu çalışmada GIST'lerin endosonografik özellikleri ile histopatolojik olarak belirlenen malign potansiyeli arasındaki ilişkilerin araştırılması amaçlanmıştır.

\section{GEREC VE YÖNTEM}

Kliniğimizde 2003-2009 yılları arasında GIST şüphesi ile EUS yapilan ve cerrahi önerilen olgular EUS kaylt sisteminden retrospektif olarak incelenmiştir. Bu olgulardan cerrahi uygulanan, histopatolojik olarak GIST tanısı konan ve detaylı patoloji raporlarına ulaşılan 25 olgu çalışmaya dahil edilmiştir.

Olguların demografik verilerine ve başvuru şikayetlerine tıbbi kayıtlarından ulaşılmıştır. Çalışmaya dahil edilen olguların retrospektif olarak patoloji raporları incelenmiş; tümör çapı, mitoz aktivitesi, Ki-67 proliferasyon indeksi değerleri kaydedilmiştir. Ayrica CD 117, CD 34, desmin, düz kas aktin, S-100 immunohistokimyasal boyanma özellikleri incelenmiş ve tümör dokusunda belirgin olan hücre tipleri tanımlanmıştır. Bu verilere dayanarak olgular NIH sınıflamasına göre çok düşük, düşük, orta ve yüksek malignite riski taşıyan GIST olarak gruplara ayrılmış ve bu gruplardaki EUS bulguları karşılaştırılmıştır.

Çalışmaya dahil edilen olguların EUS raporları ve görüntüleri yeniden gözden geçirilmiştir. Bütün endosonografik incelemeler tek kişi (A. A.) tarafından Olympus EU-M30 radial EUS sistemi kullanılarak yapılmıştır. Muskularis propria veya submukoza tabakalarından köken alan hipoekoik lezyonlar GIST

$\begin{array}{lll}\begin{array}{ll}\text { Tablo 1. NIH siniflamasina göre GIST'lerin malignite po- } \\ \text { tansiyellerinin değerlendirilmesi }\end{array} & \text { (22) } \\ & \text { Büyüklük } & \begin{array}{l}\text { Mitotik aktivite } \\ (50 \text { büyük alanda) }\end{array} \\ \text { Çok düşük risk } & <2 \mathrm{~cm} & <5 / 50 \\ \text { Düşük risk } & 2-5 \mathrm{~cm} & <5 / 50 \\ \text { Orta risk } & <5 \mathrm{~cm} & 6-10 / 50 \\ & 5-10 \mathrm{~cm} & <5 / 50 \\ \text { Yüksek risk } & >5 \mathrm{~cm} & >5 / 50 \\ & >10 \mathrm{~cm} & \text { Herhangi bir mitotik aktivite } \\ & \text { Herhangi bir çap } & >10 / 50\end{array}$

olarak tanımlanmıştır. EUS incelemesi sırasında lezyonun gastrointestinal sistemdeki lokalizasyonu, ölçülen tümör çapı, ekstralüminal sınırının düzensiz olup olmadığı, invazyon bulguları, ekojenitesi, anekoik veya hiperekoik alanların ve eşlik eden lenf nodlarının bulunup bulunmadığı ayrı ayrı incelenerek kaydedilmiştir.

İstatistik analizler SPSS 11,0 istatistik programı ile chi-square testi ve non-parametrik Kruskal Wallis testi kullanılarak yapılmıştır. Parametrik veriler için One-way ANOVA varyans analizi kullanılmıştır. $\mathrm{P}<0,05$ istatistik olarak anlamlı kabul edilmiştir.

\section{SONUÇLAR}

Çalışmaya dahil edilen 25 GIST olgusunun 13'ü erkek 12'si kadın olup yaş ortalaması 52.1ะ16.3, (26-73 yıl) olarak saptanmıştır. Dokuz (\%36) olguya üst GIS kanama, 1 (\%4) olguya reflü yakınmaları ve 15 (\%60) olguya dispeptik yakınmalar nedeni ile endoskopik inceleme yapılmış ve subepitelyal lezyon görülerek, EUS incelemesine yönlendirilmiştir. Kanama ile başvuran olguların 3'ünde birden çok üst GIS kanaması geçirme öyküsü mevcuttur.

Tüm olgulada GIST midede yerleşmiş olup, 5'i (\%20) kardiya-fundus, 17'si (\%68) korpus ve 3'ü (\%12) antrum lokalizasyonundadır (Resim 1-A). Tümörlerin ortalama çapı $51.59 \pm 20.37$ mm olarak ölçülmüştür. Kanama geçiren 9 olgu ile, dispeptik yakınmalarla başvuran 1 olguda (\%40), endoskopik incelemede tümörün lümene bakan yüzeyinde ülserasyonların varlığı görülmüştür (Resim 1-B).

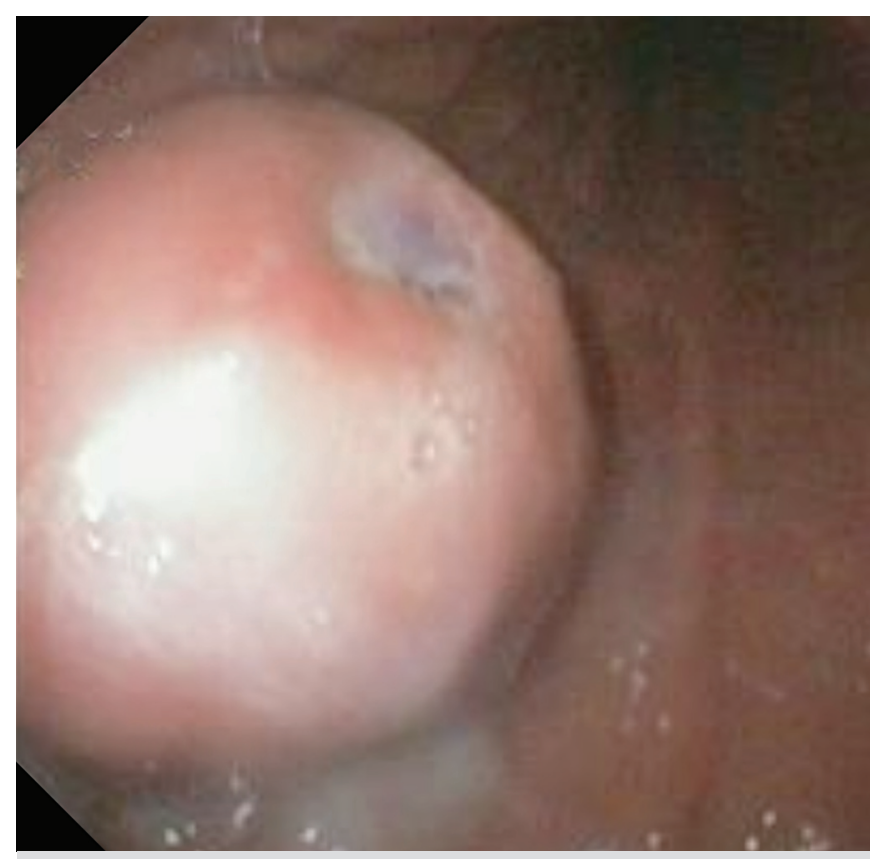

Resim 1 A. Üst gastrointestinal kanama ile başvuran olguda korpusta yerleşmiş yaklaşıı 50 mm çaplı GIST ile uyumlu lezyonun endoskopik görünümü. 


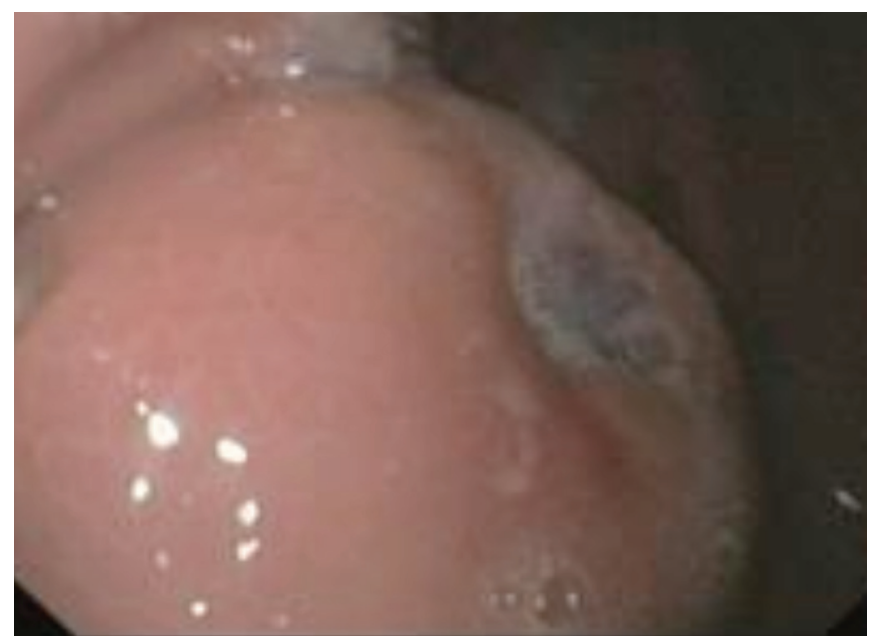

Resim 1 B. Lezyonun üzerinde kanama nedeni olabilecek iki adet ülserasyon mevcut.

Cerrahi olarak çıkarılan materyalde izlenen tümör çapı ortalama 54.30 $26.86 \mathrm{~mm}$ olarak ölçülmüş ve rapor edilmiştir. Endosonografik olarak ölçülen en geniş tümör çapı ortalamas1 $51.59 \pm 20.37 \mathrm{~mm}$ olup histopatolojik olarak ölçülen tümör çapı ile yüksek derecede koreledir ( $\mathrm{r}: 0.817, \mathrm{p}<0,001$ ) (Resim 1-C ve D). Olguların çoğunda (22 olgu, \%88), tümör iğsi hücrelerden oluşurken, 2 (\%8) olguda epitelyal hücreli ve 1 (\%4) olguda iğsi ve epitelyal hücreler içeren GIST saptanmıştır (Resim 1-E, 1-F ve 2-B). Düz kas aktin 11 (\%44) olguda, CD 34 ise 21 (\%84) olguda pozitif boyanma göstermiştir.

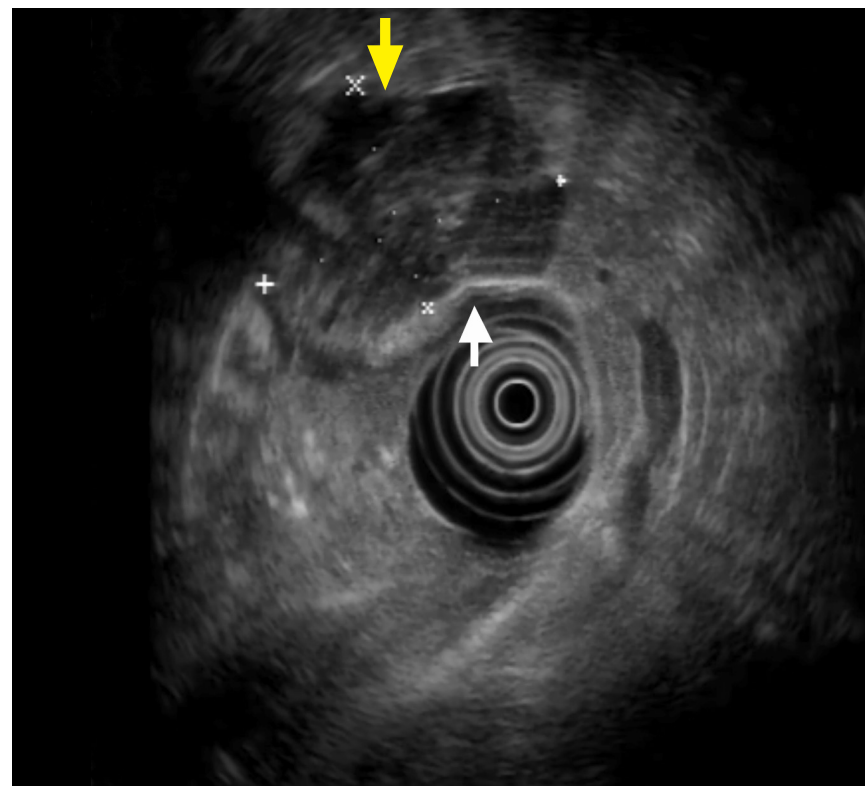

Resim 1 C. Aynı olgunun yapilan EUS incelemesinde lezyonun 55x40 mm boyutlarında submukozal yerleșimli, heterojen hipoekoik yapıda olan GIST ile uyumlu bir tümöral kitle olduğu görülüyor. Kitlenin lümene bakan yüzeyinde ülsere bağlı çöküntü mevcuttur (beyaz ok). Ayrıca ekstralüminal yüzeyde yer yer serozal invazyonu düşündüren tarzda lobülasyonlar dikkat çekiyor (sarı ok).

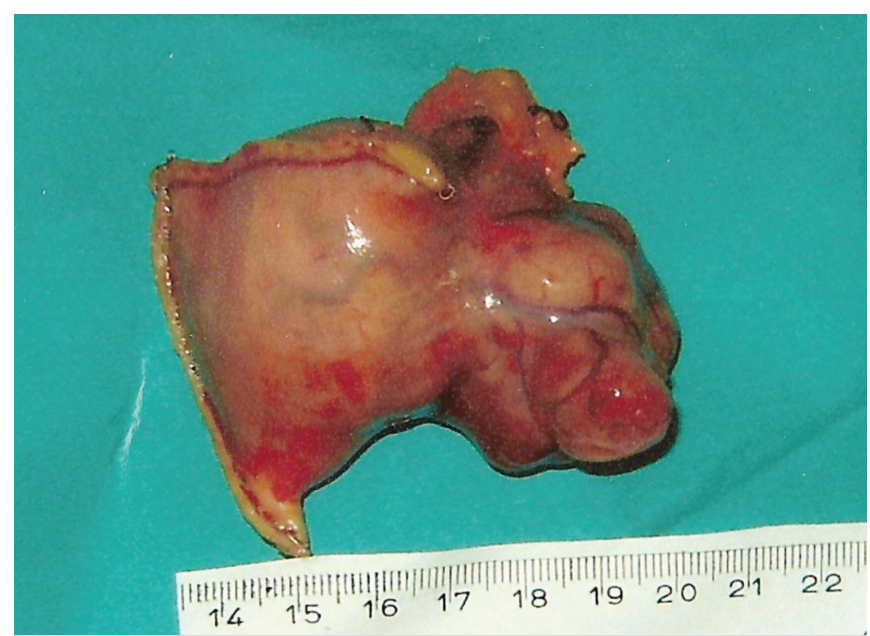

Resim 1 D. Cerrahi olarak çıkartılan lezyonun makroskopik görünümü.

Desmin 3 olguda yaygın, 1 olguda fokal boyanmıștır (\%16). S-100 tüm olgularda negatif bulunmuştur. Histopatolojik incelemede elli büyük büyütme alanında sayılan mitoz sayısı ortancası 2 olarak belirlenmiștir (0-7mitoz/BB alanı). Ki67 proliferasyon indeksi ortalama \%3.19 \pm 3.26 olarak bulunmuştur. Bu bulgular eşliğinde, NIH sinfflamasına göre GIST olgularının l'i (\%4) çok düşük, 8'i (\%32) düşük riskli, 9’u (\%36) orta riskli ve 7'si (\%28) yüksek riskli malignite potansiyeli olan GIST olarak sınıflandırılmıştır.

Olguların EUS özellikleri Tablo 2'de sunulmuştur. Tümör çapl, malignite riskinin yükselmesi ile paralel bir artış göstererek, çok düşük riskli grupta $22 \mathrm{~mm}$ iken, düşük, orta ve yüksek riskli gruplarda sirasiyla $38.23 \pm 14.7,51.7 \pm 11.9$ ve $72.8 \pm 17.9$ mm olarak bulunmuştur (Resim 2-A). Malign potansiyeli yüksek GIST grubunda ölçülen ortalama tümör çapı, diğer gruplara göre anlamlı olarak yüksektir.

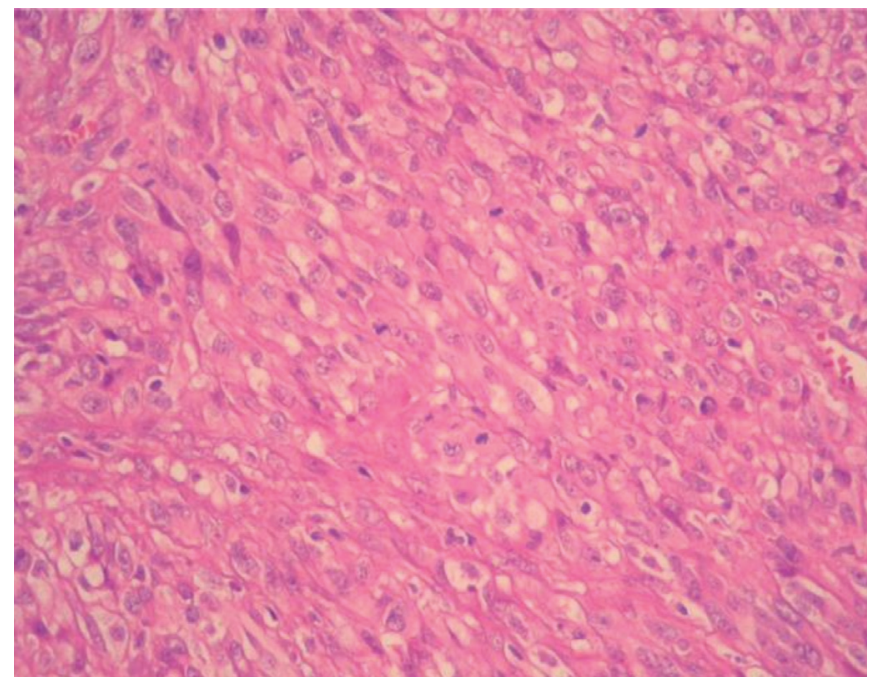

Resim $1 \mathrm{E}$. Tümörün mitotik olarak aktif olduğu bir alan. Hücreler yer yer daha epitelyal karakterde. Nukleuslar daha yuvarlak ve veziküler görünümde (Hematoksilen-eozin, x20). 


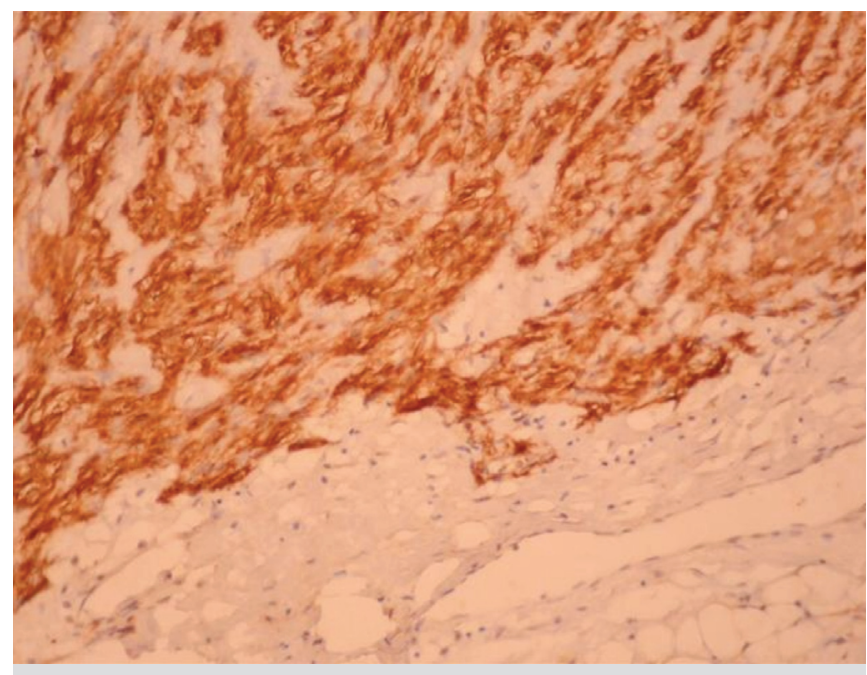

Resim $1 \mathrm{~F}$. Tümörde immunohistokimyasal olarak CD 117 pozitifliği (CD $117, \mathrm{x} 10)$

Malignite yönünden yüksek riskli olan olguların tümünde tümör çap 50 mm'den büyük bulunmuştur. Ek olarak, bu gruptaki tüm olgularda tümörler, anekoik ve hiperekoik alanlar içeren heterojen eko yapıda olup, ekstralüminal yüzeylerinde kenar düzensizliği mevcuttur (Resim 1-C). Ayrıca, yüksek riskli gruptaki olgularn \%71.4'ünde serozal invazyon, \%28.5'inde ise ülserasyon saptanmıștır.

\section{TARTIŞMA}

GIST’ler daha çok ileri yaşlarda izlenen ve erkek ve kadınları eşit oranda etkileyebilen mezenkimal tümörlerdir $(15,16)$. GIST'lerin büyük çoğunluğu midede saptanmaktadır (17). Bunu \%20-30 sıklıkla ince barsak GIST'leri izlemektedir. GIST'ler bazen sindirim kanalı dışında, karın boşluğunda da gelişebilmektedir. Bizim çalışmamızda üst gastrointestinal sistem yerleşimli GIST olguları incelenmiştir. Bu olgularda yaş ortalaması $52.1 \pm 16.3$, (26-73) yll olarak saptanmış ve erkek/kadın oranı eşit bulunmuştur. Olgularımızın tamamı mide GIST'lerinden oluşmaktadır ve çoğunda tümörlerin korpusta yerleşmiş olduğu saptanmıştır. Olguların yaş cinsiyet özellikleri ve lezyonların gastrointestinal sistem yerleşimi literatürdeki verilerle benzerlik göstermektedir (4).
GIST’ler çoğu zaman asemptomatik seyrederler. Bu olguların bir kısmı endoskopi ve diğer görüntüleme yöntemleri sırasında tesadüfen saptanırlar. Semptomatik olgular yorgunluk, dispepsi gibi nonspesifik yakınmalarla veya üst gastrointestinal kanama ile başvurabilirler (16). Agresif tümörlerde ilk bulgu karaciğer metastazı ve buna bağlı yakınmalar olabilir. Bizim serimizde olguların \%36'sı üst GIS kanaması bulguları ile kliniğimize başvurmuştur. Diğer olgularda ise nonspesifik semptomlar nedeni ile yapilan incelemelerde midede submukozal lezyondan şüphelenilmiş ve EUS incelemesi yapılmıştır. Serimizde kanamalı GIST olgularının yüksek oranda olması, bu olguların kanama nedeniyle diğer GIST olgularına göre daha sık olarak operasyona gönderilmesine bağlı olabilir.

GIST'ler genelde hiperselüler yapıda olup iğsi hücrelerin varlığı dikkat çeker. Olguların \%10 kadarında epiteloid hücreler veya her iki hücre tipi bir arada bulunabilmektedir (17). Bizim serimizde de, literatür bilgileri ile uyumlu olarak, 22 (\%88) olguda tümör iğsi hücrelerden oluşurken, 2 (\%8) olguda epitelyal hücreli ve bir (\%4) olguda iğsi ve epitelyal hücreler içeren GIST saptanmıştır. Histopatolojik olarak "tyrosin kinase receptor" markırı olan CD 117 pozitifliği tanı için değerlidir. Ek olarak, CD 34 (\%88) düz kas aktin (\%35), S-100 (\%10) ve desmin (\%5) varlığı saptanabilmektedir (18). Bizim serimizde de, literatür verileri ile uyumlu olarak, düz kas aktini \%44, CD $34 \% 84$, desmin \%16 oranında saptanmış, hiçbir olguda S-100 pozitif bulunmamıştır.

GIST'lerde en önemli problem malignite potansiyelinin değerlendirilmesidir. Endoskopi gastrointestinal kanalın incelenmesinde altın standart bir yöntem olmakla birlikte özellikle submukozal lezyonların incelenmesinde yetersiz kalmaktadır. EUS, GIST'lerin tanısında ve diğer submukozal neoplazmlardan ayırıcı tanısında en değerli görüntüleme yöntemidir (19). GIST'ler endosonografik olarak hipoekoik lezyonlar olarak görülür. Bazı olgularda, muscularis propria tabakası ile devamllık gösterdiği izlenebilir. EUS incelemesi sırasında GIST’lerin büyüklügüu, yerleşimi, ekojenitesi, ekstralüminal s1nırı, anekoik ya da hiperekoik alanların bulunup bulunmadığı incelenmektedir (19). Özellikle ekstralüminal yüzeyde düzensizlik olması, tümörün invaziv olduğunun bir göstergesi olabilir $(20,21)$. Bu çalışmada, histopatolojik olarak yüksek

$\begin{array}{lccccc}\text { Tablo 2. NIH risk siniflamasına göre GIST'lerin EUS bulguları } & & & \\ & \text { Çok düşük (1) } & \text { Düşük (8) } & \text { Orta (9) } & \text { Malign (7) } & \text { P } \\ \text { Tümör çapı (mm) } & 22 & 38.23 \pm 14.7 & 51.7 \pm 11.9 & 72.8 \pm 17.9 & <0.01 \\ \text { Kenar düzensizliği } & 0(\% 0) & 0(\% 0) & 1(\% 11) & 7(\% 100) & <0,001 \\ \text { Serozal invazyon } & 0(\% 0) & 0(\% 0) & 1(\% 11) & 5(\% 71.4) & <0.01 \\ \text { Ülserasyon } & 0(\% 0) & 3(\% 37.5) & 5(\% 55.5) & 2(\% 28.5) & \text { AD } \\ \text { Anekoik alanlar } & 0(\% 0) & 5(\% 62.5) & 7(\% 77.7) & 7(\% 100) & \text { AD } \\ \text { Hiperekojen alanlar } & 0(\% 0) & 2(\% 25) & 6(\% 66.6) & 7(\% 100) & <0.05\end{array}$

NIH: National Institutes of Health EUS: Endosonografi 

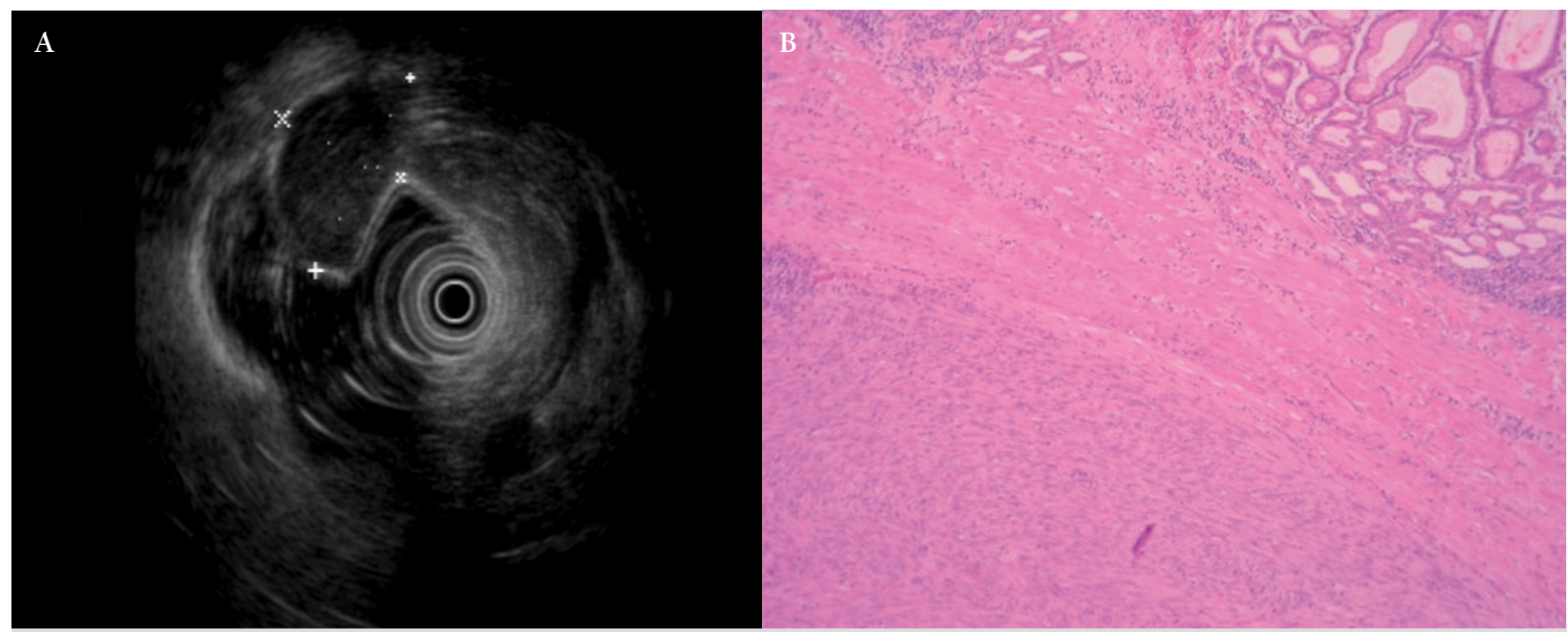

Resim 2. Dispeptik yakınmalarla bașvuran olgunun EUS incelemesinde $38 x 25 \mathrm{~mm}$ boyutlarında, submukozal yerleşimli, düzgün konturlu, genel olarak homojen hipoekoik yapıda GIST ile uyumlu olan tümöral bir kitle izleniyor (2 A). Aynı olgunun histopatolojik incelemesinde submukozal yerleşimli iğsi hücrelerden oluşmuş GIST izleniyor (Hematoksilen-eozin, x10) (2 B)

riskli malign GIST olarak tanımlanan lezyonların tamamının sınırlarında düzensizlik izlenmiştir. Buna karşın düzgün sınırlı, 30 mm'den küçük, homojen hipoekoik lezyonlar, malignite riski düşük/benign GIST’i düşündürür. Çalışmamızda bu özelliklere sahip bütün lezyonlar histopatolojik olarak çok düşük ve düşük riskli GIST olarak sınıflandırılmıştır. Bulgularımız EUS verilerinin GIST'in malign potansiyeli tahmin etmede sensitif ve spesifik bir yöntem olduğunu göstermektedir.

GIST'lerin endosonografik özelliklerini içeren çok sayıda çalışma yapılmıştır. Ancak bu serilerde olguların çoğu histopatolojik olarak incelenmemiştir. Chak ve arkadaşları endosonografik olarak GIST'lerin çapının 4 cm'den büyük olmasını, hiperekoik alanların varlığını, lezyonun şekil veya sınır düzensizliğini, malignite potansiyelini gösteren bulgular olarak yorumlamışlardır (20). Bu özelliklerin birkaçının bir arada olması durumunda EUS \%100'e yakın duyarlılıkla malign lezyonları saptayabilmektedir (21). Bizim çalışmamızda EUS

\section{KAYNAKLAR}

1. Goettsch WG, Bos SD, Breekveldt-Postma N, et al. Incidence of gastrointestinal stromal tumours is underestimated: results of a nation-wide study. Eur J Cancer 2005;41:2868-72.

2. Tryggvason G, Gislason HG, Magnusson MK, Jonasson JG. Gastrointestinal stromal tumors in Iceland, 1990-2003: The Icelandic GIST study, a population-based incidence and pathologic risk stratification study. Int J Cancer 2005;117:289-93.

3. Miettinen M, Majidi M, Lasota J. Pathology and diagnostic criteria of gastrointestinal stromal tumors (GISTs): A review. Eur J Cancer 2002;38:39-51.

4. Pidhorecky I, Cheney RT, Kraybill WG, Gibbs JF. Gastrointestinal stromal tumors: current diagnosis, biologic behavior, and management. Ann Surg Oncol 2000;7:705-12. bulguları ile histopatolojik veriler korele edilmiştir. Bulgularımiza göre, endosonografik olarak 50 mm'den büyük, kenarları düzensiz olan, içinde hiperekoik ve anekoik alanlar bulunan heterojen eko yapıdaki lezyonlar malignite riski yüksek GIST olarak değerlendirilmelidir. Bu bulgular daha önce yayınlanan çalışmalarla uyumludur (8). Lümene bakan yüzeyde ülserasyon varlığı malign potansiyelden bağımsız olarak izlenmiştir. Ülserasyon varlığı, düşük riskli grupta \%37,5, orta riskli grupta \%55.5 oranında saptanırken, yüksek riskli gruptaki olgularda sadece \%28.5 oranında bulunmuştur.

Sonuç olarak EUS, GIST'lerin tanı ve malignite potansiyellerinin değerlendirilmesinde güvenilir bir yöntemdir. Endosonografik olarak 50 mm'den büyük, kenarları düzensiz, içinde anekoik ve hiperekoik alanlar bulunan heterojen ekojeniteli lezyonlar muhtemel malign lezyonlar olarak değerlendirilmelidir. Ancak tüm GIST'lerin malign potansiyele sahip olduğu göz önüne alınarak, opere edilmeyen olgularda histopatolojik inceleme ve takip yapılmalıdır.

5. Scarpa M, Bertin M, Ruffolo C, et al. A systematic review on the clinical diagnosis of gastrointestinal stromal tumors. Surg Oncol 2008;98384-92.

6. Belloni M, De Fiori E, Mazzarol G, et al. Endoscopic ultrasound and computed tomography in gastric stromal tumours. Radiol Med 2002;103:65-73.

7. Okai T, Minamoto T, Ohtsubo K, et al. Endosonographic evaluation of c-kit-positive gastrointestinal stromal tumor. Abdom Imag 2003;28:3017.

8. Shah P, Gao F, Edmundowicz SA, et al. Predicting malignant potential of gastrointestinal stromal tumors using endoscopic ultrasound. Dig Dis Sci 2008;29.e-pub. 
9. Chatzipantelis P, Salla C, Karoumpalis I, et al. Endoscopic ultrasoundguided fine needle aspiration biopsy in the diagnosis of gastrointestinal stromal tumors of the stomach. A study of 17 cases. J Gastrointestin Liver Dis 2008; 17:15-20.

10. DeMatteo RP, Lewis JJ, Leung D, et al. Two hundred gastrointestinal stromal tumors: recurrence patterns and prognostic factors for survival. Ann Surg 2000;231:51-8.

11. Franquemont DW. Differentiation and risk assessment of gastrointestinal stromal tumors. Am J Clin Pathol 1995;103:41-7.

12. Emory TS, Sobin LH, Lukes L, et al. Prognosis of gastrointestinal smooth-muscle (stromal) tumors: dependence on anatomic site. Am J Surg Pathol 1999;23:82-7.

13. Yang HK, Park Do J, Lee HJ, et al. Clinicopathologic characteristics of gastrointestinal stromal tumor of the stomach. Hepatogastroenterology 2008;55:1925-30

14. Joensuu H. Risk stratification of patients diagnosed with gastrointestinal stromal tumor. Hum Pathol 2008;39:1411-9.

15. Lee YT. Leiomyosarcoma of the gastrointestinal tract: General pattern of metastasis and recurrence. Cancer Treat Rev 1983;10:91-101.
16. Morrissey K, Cho ES, Gray GF Jr, Thorbjarnarson B. Muscular tumors of the stomach: Clinical and pathological cases. Ann Surg 1973;178:14855

17. Steigen SE, Eide TJ. Gastrointestinal stromal tumors (GISTs): a review. APMIS 2009;117:73-86

18. Miettinen M, Sobin LH, Sarlomo-Rikala M. Immunohistochemical spectrum of GISTs at different sites and their differential diagnosis with a reference to CD117 (KIT). Mod Pathol 2000;13:1134-42.

19. Yamada Y, Kida M, Sakaguchi T, et al. A study on myogenic tumors of the upper gastrointestinal tract by endoscopic ultrasonography. Dig Endosc 1992;4:396-408.

20. Chak A, Canto MI, Rosch T, et al. Endosonographic differentiation of benign and malignant stromal cell tumors. Gastrointest Endosc 1997; 45:468-73

21. Palazzo L, Land B, Cellier C, et al. Endosonographic features predictive of benign and malignant gastrointestinal stromal tumours. Gut 2000;46:88-92

22. Fletcher DM, Berman JJ, Corless C, et al. Diagnosis of gastrointestinal stromal tumors: a consensus approach. Hum Pathol 2002;33:459-65. 